\title{
APLIKASI SABUT KELAPA DAN PUPUK BOKASI KOTORAN AYAM TERHADAP PERTUMBUHAN BIBIT SAWIT DI PRE NURSERI
}

\section{APPLICATION OF COCONUTFIBRE AND CHICKEN MANURE ON OIL PALM SEEDLING GRTOWTH IN PRENUSERY}

\author{
${ }^{1 *}$ Iqbal Effendy, ${ }^{2}$ Gribaldi dan ${ }^{3}$ Benny Abdul Jalal \\ ${ }^{1,3}$ Program Studi Agroteknologi Fakultas Pertanian Universitas Musi Rawas \\ J1. Pembangunan Kompleks Perkantoran Pemkab Mura, Lubuklinggau \\ Tlp / Fax 0733-451321 \\ ${ }^{2}$ Program Studi Agroteknologi Fakultas Pertanian Universitas Baturaja \\ J1. Ki. Ratu Penghulu No.02301 Karang Sari Baturaja \\ Tlp/Fax. 0735-326122 \\ * Penulis untuk korespondensi: Telp. 081373562110 \\ email: iqbaleffendy47@yahoo.com
}

\begin{abstract}
ABSTRAK
Penggunaan bibit kelapa sawit yang bermutu akan menentukan keberhasilan jangka panjang pengelolaan perkebunan kelapa sawit. Salah satu faktor yang menentukan keberhasilan pembibitan kelapa sawit di tingkat prenursery adalah ketersediaan air yang cukup. Bila terjadi kekurangan air dapat mengakibatkan penyimpangan pertumbuhan dan menghasilkan bibit yang tidak prima. Penelitian ini bertujuan untuk melihat kemampuan sabut kelapayang dikombinasikan dengan pupuk bokasi kotoran ayam untuk menahan air di dalam polibag terhadap pertumbuhan bibit, menggunakan Rancangan Acak Kelompok (RAK) yang disusun secara faktorial, terdiri dari dua faktor perlakuan dan tiga kali ulangan. Faktor pertama adalah bobot sabut kelapa (S) terdiri dari 3 level yaitu : $\mathrm{S} 0=0 \mathrm{~g}, \mathrm{~S} 1=25 \mathrm{~g}$ dan $\mathrm{S} 2=50 \mathrm{~g}$ per polibag. Faktor kedua bobot pupuk bokasi kotoran ayam (B) terdiri dari 4 level yaitu B1 =50g,B2 = $100 \mathrm{~g}, \mathrm{~B} 3=150 \mathrm{gdan} \mathrm{B} 4=200$ g per polibag.tanah yang digunakan dalam penelitian ini adalah tanah Ultisol (PMK seberat $10 \mathrm{~kg}$ per polibag. Hasil penelitian menunjukkan bahwa penambahan sabut kelapa $50 \mathrm{~g}$ dan bokasi kotoran ayam $200 \mathrm{~g}$ per polibag seacra tunggal memberikan pengaruh yang nyata terhadap pertumbuhan bibit kelapa sawit di pre nursery, namun tidak terdapat interaksi diantara kedua perlakuan.
\end{abstract}

Kata kunci :bokasi kotoran ayam, kelapa sawit, sabut kelapa

\section{PENDAHULUAN}

Kelapa sawit (Elaeis guineensis Jacq.) merupakan tanaman perkebunan dan berperan penting dalam peningkatan devisa negara, penyerapan tenaga kerja dan peningkatan perekonomian di Indonesia (Corley \& Tinker, 2016, Mira et al., 2017 dan Waruwu et al., 2018), merupakan tanamanpenghasil minyak nabati tertinggi diantara tanaman penghasil minyak lain, mencapai 5,5-7,3 ton per ha per tahun minyak sawit mentah (Effendy, 2016).Luas areal perkebunan kelapa sawit di Indonesia tahun 2017 mencapai 12.3 juta ha dan merupakan perkebunan kelapa sawit yang terluas di dunia. Demikian pula produksi minyak sawit Indonesia tahun 2017 mencapai 35,3 juta ton dan menduduki posisi pertama di dunia (Direktorat Jendral Perkebunan, 2017). Namun rata-rata produktivitas perkebunan rakyat kelapa sawit di Indonesia masih sangat rendah berkisar 5 ton TBS ha-1 tahun $^{-1}$, sementara potensi produksi bisa mencapai 20 - 30 ton TBS per ha per tahun(Herman \& Pranowo, 2011).

Rendahnya produktivitas kebun sawit rakyat ini disinyalir salah satu penyebabnya adalah penggunaan bibit yang tidak tepat disamping pengelolaan budidaya yang belum standart. Pengelolaan kebun kelapa sawit dengan menggunaan bibit yang bermutu, merupakan salah satu faktor yang menentukan produktivitas kebun kelapa sawit, sebagaimana dinyatakan oleh Asmono et al.( 2003),bibit kelapa sawit yang prima memiliki kekuatan dan penampilan tumbuh yang optimal serta berkemampuan dalam menghadapi kondisi cekaman lingkungan saat pelaksanaan transplanting yangmerupakan awal dari kegiatan budidaya tanaman kelapa sawit. Oleh sebab itu pemilihan benih, bibit, media tanam, pemupukan, dan pemeliharaan kelembaban media tanam menjadi hal utama yang diperhatikan selama proses pembibitan (Efendi, 2014).Untuk mendapatkan bibit dengan kualitas prima akan sangat tergatung pada 
media tanam pembibitan yang baik secara fisik, kimia dan biologi, dimana hal ini akan mempengaruhi secara langsung pertumbuhan akar, sejalan dengan pendapat Khan et al., (2006), yang mengatakan bahwa media tanam harus porius dan tidak menahan air, memudahkan penetrasi akar dan memiliki hara yang cukup untuk mendukung pertumbuhan bibit tanaman.

Ketersediaan air bagi pembibitan kelapa sawit baik di tingkat pre nusery atau di main nursery sangat menetukan keberhasilan pembibitan. Air dibutuhkan oleh tanaman sebagai komponen utama dalam sel yang menyusun jaringan, berperan dalam berbagai reaksi metabolisma seperti proses difusi, osmosis, transport aktif, fotosintesis, transpirasi dan lain-lain (Hidayat et al., 2013). Penyiraman bibit di pre nursery harus diperhatikan untuk mencegah terjadinya kelainan pada bibit, atau kematian bibit yang dibudidayakan akibat kekeringan. Cekaman kekeringan atau kekurangan air pada media tumbuh berakibat pada penurunan tekanan turgor, penutupan stomata, penurunan luas daun, penurunan laju fotosintesis yang pada alhirnya menyebabkan penurunan laju pertumbuhan (Jaleel et al., 2008 dan Tezara et al., 2002). Tanaman kelapa sawit menghendaki penyiraman dengan standar penyiraman di pre nursery, tiap bibit memerlukan 0.2-0.3 liter air per polibag per hari (Anonimous, 2018). Salah satu alternatif yang dapat digunakan untuk meningkatkan daya simpan air dalam polibag adalah melakukan pencampuran media tanam bibit kelapa sawitdengan sabut kelapa. Sabut kelapa merupakan limbah lignoselulosa yang mempunyai potensi besar untuk dimanfaatkan sebagai bahan campuran media tanam di polibag. Karakteristik yang dimiliki abu sabut kelapa, menurut Risnah et al.,( 2013) dari hasil analisis menunjukkan kondisi $\mathrm{pH}$ yang tinggi yaitu 11,77 , COrganik yang rendah $0,01 \%, \mathrm{~N}$ total dan $\mathrm{P}$ total yang rendah yaitu $0,03 \%$ dan $2,31 \%$, tetapi kandungan $\mathrm{K}$ total yang tinggi yaitu $21,87 \%$ serta nilai kapasitas pertukaran kation yang baik yaitu 13,29 me per $100 \mathrm{~g}$. Hasriani et al., (2013) menyatakan bahwa media yang ditambah dengan sabut kelapa memiliki daya simpan air yang tinggi dibandingkan dengan media tanah tanpa campuran. Penambahan material seperti debu sabut kelapa dan bahan organik lain pada media tumbuh bibit kelapa sawit telah dilaporkan penggunaannya oleh peneliti terdahulu (Khairil et al., 2012) yang menyimpulkan berpengaruh positif terhadap pertumbuhan bibit dan perbaikan sifat-sifat fiksik tanah. Kekurangan air pada pre nursery menyebabkan bibit dengan daun berkerut (Crinkle leaf) yaitu bibit dengan pertumbuhan daun yang mengkerut terhambat di bagian tengah yang menyebabkan pertumbuhan daun terhambat. Hal ini dapat disebabkan oleh faktor genetik dan lingkungan khususnya cekaman kekeringan(Rosa \& Zaman, 2017).

Selain media tanam, upaya untuk mendapatkan bibit yang baik dan berkualitas ialah dengan melakukan pemupukan pada media pembibitan. Pemberian pupuk di pembibitan merupakan salah satu langkah penting agar pertumbuhan dan perkembangan bibit dapat optimal (Ariyanti et al.,2017 dan Sari et al., 2015)), bahwa titik kritis pemeliharaan bibit kelapa sawit terletak pada pemupukan yang dimulai dari pembibitan awal sampai pembibitan utama. Tanah dalam polibag tidak boleh memiliki keterbatasan hara. Pupuk yang diberikan pada bibit berdasarkan sifat senyawanya ada dua jenis, yaitu pupuk organik dan pupuk anorganik (Sutanto, 2002).

Salah satu pupuk organik yang dapat digunakan ialah pupuk bokasi. Pupuk organik bokasi merupakan bahan pembenah tanah yang paling baik dan alami dari pada bahan pembenah buatan atau pembenah sintesis. Pada umumnya pupuk ini mengandung hara makro nitogen, fosfor, dan kalium,juga mengandung hara mikro dalam jumlah cukup yang sangat diperlukan pertumbuhan tanaman. Sebagai bahan pembenah tanah, mencegah terjadinya erosi, pergerakan permukaan tanah (Crusting) dan retakan tanah, mempertahankan kelengasan tanah serta memperbaiki pengatusan (Internal drainase) (Sutanto, 2002).

Pupuk kandang bokasi menurut Wididana et al., (1996) dapat memperbaiki sifat fisika, kimia, dan biologi tanah, meningkatkan produksi tanaman dan menjaga kestabilan produksi tanaman, serta menghasilkan kualitas dan kuantitas hasil pertanian yang berwawasan lingkungan. Pupuk bokasi dapat meningkatkan unsur hara tanah, serta memperbaiki sifat fisika, kimia, dan biologi tanah, walaupun pupuk anorganik masih diperlukan untuk memenuhi kebutuhan hara (Cahyani, 2003). Pupuk bokasi dapat dimanfaatkan untuk meningkatkan kandungan material organik pada tanah yang keras seperti tanah podzolik merah kuning (Ultisol) sehingga dapat meningkatkan aerasi tanah dan mengurangi bulk density tanah (Susilawati, 2000).

Selanjutnya ditambahkan oleh Loekito(1998), pemberian bokasi untuk tanaman tahunan sebagaipupuk dasar pada saat di pembibitan berkisar 50 -150 g per polybag. Selanjutnya Herviyanti et al. (2012) menyatakan kandungan bahan organik yang tinggi pada tanah mampu meningkatkan efektivitas pemupukan karena mampu mengikat unsur hara dan meningkatkan kapasitas tukar kation tanah. Penentuan dosis yang tepat sangat diperlukan, karena kekurangan atau kelebihan 
unsur hara dapat mengganggu pertumbuhan dan perkembangan tanaman (Suryati \& Anom, 2014).Atas dasar uraian diatas, peneliti merasa perlu untuk melakukan penelitian dengan tujuan melihat kemampuan sabut kelapa dalam menahan air di dalam polibag, dikombinasikan dengan pupuk kotoran ayam yang diharapkan dapat memperbaiki sifat fisik, kimia dan bilogis tanah terhadap pertumbuhan bibit kelapa sawit dalam polibag pada tingkat pembibitan pre nursery.

\section{METODE PENELITIAN}

Penelitian ini dilaksanakan di Kecamatan Lubuklinggau Timur I Kota Lubuklinggau dengan ketinggian tempat $100 \mathrm{~m} \mathrm{dpl}$, pada Maret hingga Mei 2017. Bahan yang digunakan pada penelitian ini adalah kecambah kelapa sawit varietas Marihat, sabut kelapa kering, pupuk bokasi kotoran ayam yang telah difermentasi menggunakan EM4, tanah Ultisol dan pupuk NPK 15:15:15. Penelitian ini menggunakan Rancangan Acak Kelompok (RAK) faktorial terdiri dari dua faktor. Faktor pertama bobot sabut kelapa (S) dengan tiga aras yaitu $\mathrm{S} 0=0 \mathrm{~g}, \mathrm{~S} 1=25 \mathrm{~g}$ dan $\mathrm{S} 2=50 \mathrm{~g}$ per polibag. Faktor kedua bobot bokasi kotoran ayam (B) terdiri dari 4 aras yaitu :B1 $=50 \mathrm{~g}, \mathrm{~B} 2=100 \mathrm{~g}, \mathrm{~B} 3=$ $150 \mathrm{~g}$ dan $\mathrm{B} 4=200 \mathrm{~g}$ per polibag. Terdapat 12 kombinasi perlakuan yang diulang 3 kali. Setiap kombinasi perlakuan terdiri atas 3 tanaman sebagai tanaman contoh, sehingga dibutuhkan 108 polibag. Sabut kelapa yang digunakan adalah dari jenis dan umur buah kelapa yang sama dan terlebih dahulu dikering anginkan, kemudian ditimbang sesuai dengan perlakuan. Sabut kelapa dimasukan kedalam polibag sesuai dengan takaran, kemudian diisi tanah Ultisol (PMK) yang telah dicampur dengan bokasi kotoran ayam sesuai takaran perlakuan hingga mencapai berat $10 \mathrm{~kg}$ per polibag. Pupuk NPK 15:15:15 sebanyak $10 \mathrm{~g}$ per polibag disebar merata diatas permukaan tanah dalam polibag dan dibiarkan selama satu minggu. Kemudian dilakukan penanaman kecambah kelapa sawit dengan memperhatikan arah plumula dan radikula. Penyiraman dilakukan setiap hari (takaran air $200 \mathrm{ml}$ per polibag). Parameter pengamatan meliputi : 1. Tinggi bibit, 2. Jumlah pelepah 3. Diameter batang, 4. Bobot kering tajuk dan 5. Bobot kering total, dilakukan pada akhir penelitian yaitu saat bibit berumur 90 hari. Analisis varian pada taraf $5 \%$ dilakukan untuk melihat pengaruh perlakuan terhadap parameter penduga dan bila terdapat pengaruh nyata, dilanjutkan dengan uji Beda Nyata Jujur pada taraf 5 \%. (Paiman, 2013).

\section{HASIL DAN PEMBAHASAN}

Hasil analisis keragaman pengaruh sabut kelapa dan takaran pupuk bokasi kotoran ayam terhadap pertumbuhan bibit kelapa menunjukkan bahwa perlakuan pupuk bokasi kotoran ayam berpengaruh nyata pada peubah tinggi bibit, bobot kering tajuk dan bobot kering total bibit, tidak berpengaruh nyata terhadap jumlah pelepah. Pemberian sabut kelapa berpengaruh nyata terhadap tinggi bibit, berat kering tajuk dan berat kering total dan tidak berpengaruh nyata terhadap jumlah pelepah. Sementara interaksi kedua perlakuan menunjukkan pengaruh yang tidak nyata terhadap semua perlakuan.

Hasil analisis varian pengaruh sabut kelapa dan takaran bokasi kotoran ayam terhadap pertumbuhan bibit kelapa menunjukkan bahwa pemberian bokasi kotoran ayam berpengaruh nyata terhadap tinggi bibit, bobot kering tajuk dan bobot kering total tetapi tidak berpengaruh terhadapjumlah pelepah.Pemberian sabut kelapaberpengaruh nyata terhadap tinggi bibit, bobot kering tajuk dan bobot kering total dan tidak berpengaruh terhadap jumlah pelepah. Interaksi kedua perlakuan tidak berpengaruh nyata terhadap tinggi bibit, jumlah pelepah, bobot kering tajuk dan bobot kering total.

Hasil Uji BNJ pada taraf 5\% menunjukkan perlakuan pupuk kotoran ayam $200 \mathrm{~g}$ per polibag (B4) berbeda nyata dengan B2 dan B3 dan B1. Bibit kelapa sawit tertinggi diperoleh pada perlakuan $\mathrm{B} 4$ yaitu dengan rata-rata $21,13 \mathrm{~cm}$ dan terendah pada perlakuan $\mathrm{B} 1$ yaitu dengan rata-rata $18,05 \mathrm{~cm}$, hal ini menunjukkan peningkatan takaran pupuk bokasi kotoran ayam dari $50 \mathrm{~g}$ menjadi $200 \mathrm{~g}$ per polibag dapat meningkatkan tinggi bibit sebesar $16,93 \%$. Penambahan sabut kelapa hingga $50 \mathrm{~g}$ per polibag dapat menambah tinggi bibit kelapa sawit ini sebesar 5,63\%. Tidak terdapat interaksi kedua perlakuan terhadap tinggi bibit, namun terdapat kecenderungan kombinasi pemberian sabut kelapa $50 \mathrm{~g}$ per polibag dengan pemberian bokasi $200 \mathrm{~g}$ per polibag memberikan hasil tinggi bibit yang terbaik yaitu 23,20 cm (Tabel 1). 
Tabel 1. Pengaruh pupuk bokasi kotoran ayam dan sabut kelapa terhadap tinggi bibit kelapa sawit (cm)

\begin{tabular}{|c|c|c|c|c|}
\hline \multirow{2}{*}{$\begin{array}{c}\text { Takaran pupuk bokasi } \\
\text { kotoran ayam }\end{array}$} & \multicolumn{3}{|c|}{ Sabut kelapa } & \multirow{2}{*}{ Rerata } \\
\hline & $\mathrm{S} 0=0 \mathrm{~g}$ sabut & $\mathrm{S} 1=25 \mathrm{~g}$ sabut & $\mathrm{S} 2=50 \mathrm{~g}$ sabut & \\
\hline $\mathrm{B} 1=50 \mathrm{~g}$ & 18,98 & 17,64 & 17,52 & $18,05 \mathrm{a}$ \\
\hline $\mathrm{B} 2=100 \mathrm{~g}$ & 19,55 & 19,23 & 19,02 & $19,27 \mathrm{~b}$ \\
\hline $\mathrm{B} 3=150 \mathrm{~g}$ & 16,67 & 19,53 & 18,99 & $18,40 \mathrm{ab}$ \\
\hline $\mathrm{B} 4=200 \mathrm{~g}$ & 19,33 & 20,87 & 23,20 & $21,13 \mathrm{c}$ \\
\hline Rerata & $18,63 \mathrm{a}$ & $19,32 \mathrm{ab}$ & $19,68 \mathrm{~b}$ & \\
\hline
\end{tabular}

Keterangan : Angka rerata yang diikuti oleh huruf yang sama pada kolom dan baris yang

sama berarti tidak berbeda nyata pada uji BNJ taraf 5\%.

Tabel 2. Pengaruh bokasi kotoran ayam dan sabut kelapa terhadap jumlah pelepah kelapa sawit.

\begin{tabular}{|c|c|c|c|c|}
\hline \multirow{2}{*}{$\begin{array}{c}\text { Takaran pupuk bokasi } \\
\text { kotoran ayam }\end{array}$} & \multicolumn{3}{|c|}{ Sabut kelapa (S) } & \multirow{2}{*}{ Rerata } \\
\hline & $\mathrm{S} 0=0 \mathrm{~g}$ sabut & $\mathrm{S} 1=25 \mathrm{~g}$ sabut & $\mathrm{S} 2=50 \mathrm{~g}$ sabut & \\
\hline $\mathrm{B} 1=50 \mathrm{~g}$ & 3,44 & 4,07 & 3,99 & $3,80 \mathrm{a}$ \\
\hline $\mathrm{B} 2=100 \mathrm{~g}$ & 4,33 & 4,44 & 4,44 & $4,41 \mathrm{a}$ \\
\hline $\mathrm{B} 3=150 \mathrm{~g}$ & 4,67 & 4,33 & 4,25 & $4,42 \mathrm{a}$ \\
\hline $\mathrm{B} 4=200 \mathrm{~g}$ & 4,43 & 4,63 & 4,56 & $4,54 \mathrm{a}$ \\
\hline Rerata & $4,22 \mathrm{a}$ & $4,37 \mathrm{a}$ & $4,29 \mathrm{a}$ & \\
\hline BNJ bokasi kotoran ayam & 1,08 & BNJ sabut kelapa &, 02 & \\
\hline
\end{tabular}

Keterangan : angka rerata yang dikuti oleh huruf yang sama pada kolom danbaris yang sama berarti berbeda tidak nyata pada uji BNJ taraf uji 5\%.

Hasil analisis varian terhadap peubah jumlah pelepah menunjukkan pengaruh yang tidak nyata baik perlakuan pemberian bokasi kotoran ayam maupun pemberian sabut kelapa, demikian juga interaksi kedua perlakuan tidak menunjukkan pengaruh yang nyata. Secara tabulasi terlihat jumlah pelepah tertinggi pada perlakuan pemberian pupuk bokasi kotoran ayam $200 \mathrm{~g}$ dengan rata-rata jumlah pelepah 4,54 pelepah dan terendah pada perlakuan B1 yaitu 3,80 pelepah, berarti hanya dapat meningkatkan jumlah pelepah sebesar 19,47 \%. Pengaruh pemberian sabut kelapa terhadap jumlah pelepah terlihat pada perlakuan pemberian $25 \mathrm{~g}$ sabut kelapa per polibag yaitu 4,37 pelepah dan interaksinya pada kombinasi perlakuan sabut kelapa $25 \mathrm{~g}$ per polibag dengan pemberian bokasi kotoran ayam 200 g per polibag yaitu 4,63 pelepah (Tabel 2).
Pengamatan terhadap bobot kering tajuk bibit, baik pupuk bokasi kotoran ayam dan perlakuan sabut kelapa memberikan pengaruh yang nyata terhadap bobot kering tajuk. Bobot kering tajuk tertinggi terdapat pada perlakuan B4 (200 g bokasi per polibag) yaitu sebesar $0,21 \mathrm{~g}$, yang berarti terjadi peningkatan bobot kering tajuk sebesar 23,52 \% dari pemberian bokasi B1 (50 g bokasi per polibag) dan pemberian sabut kelapa $\mathrm{S} 2$ ( $50 \mathrm{~g}$ sabut per polibag) dapat meningkatkan berat kering tajuk sebesar 17,64 \% (Tabel 3). 
Tabel 3. Pengaruh pupuk bokasi kotoran ayam dan sabut kelapa terhadap bobot kering tajuk bibit kelapa sawit (g)

\begin{tabular}{lcccc}
\hline \multirow{2}{*}{$\begin{array}{c}\text { Takaran pupuk bokasi } \\
\text { kotoran ayam }\end{array}$} & \multicolumn{3}{c}{ Sabut kelapa (S) } & Rerata \\
\cline { 2 - 4 } & $\mathrm{S} 0=0 \mathrm{~g}$ sabut & $\mathrm{S} 1=25 \mathrm{~g}$ sabut & $\mathrm{S} 2=50 \mathrm{~g}$ sabut & \\
\hline $\mathrm{B} 1=50 \mathrm{~g}$ & 0,16 & 0,18 & 0,16 & $0,17 \mathrm{a}$ \\
$\mathrm{B} 2=100 \mathrm{~g}$ & 0,16 & 0,18 & 0,20 & $0,18 \mathrm{ab}$ \\
$\mathrm{B} 3=150 \mathrm{~g}$ & 0,17 & 0,20 & 0,20 & $0,19 \mathrm{~b}$ \\
$\mathrm{~B} 4=200 \mathrm{~g}$ & 0,19 & 0,21 & 0,24 & $0,21 \mathrm{~d}$ \\
\hline \multicolumn{2}{c}{ Rerata } & $0,17 \mathrm{a}$ & $0,19 \mathrm{bc}$ & $0,20 \mathrm{c}$ \\
\hline BNJ bokasi kotoran ayam & $=0,01$ & BNJ sabut kelapa $=0,01$ & \\
\hline
\end{tabular}

Keterangan : angka rerata yang diikuti oleh huruf yang sama pada kolom dan baris yang sama berarti berbeda tidak nyata pada uji BNJ taraf uji $5 \%$.

Tabel 4.Pengaruh pupuk bokasi kotoran ayam dan sabut kelapa terhadap bobot kering total bibit kelapa sawit (g)

Pemhahasan.

\begin{tabular}{|c|c|c|c|c|}
\hline \multirow{2}{*}{$\begin{array}{c}\text { Takaran pupuk bokasi } \\
\text { kotoran ayam }\end{array}$} & \multicolumn{3}{|c|}{ Sabut kelapa (S) } & \multirow{2}{*}{ Rerata } \\
\hline & $\mathrm{S} 0=0 \mathrm{~g}$ sabut & $\mathrm{S} 1=25 \mathrm{~g}$ sabut & $\mathrm{S} 2=50 \mathrm{~g}$ sabut & \\
\hline $\mathrm{B} 1=50 \mathrm{~g}$ & 0,20 & 0,24 & 0,22 & $0,22 \mathrm{a}$ \\
\hline $\mathrm{B} 2=100 \mathrm{~g}$ & 0,22 & 0,24 & 0,25 & $0,24 \mathrm{a}$ \\
\hline $\mathrm{B} 3=150 \mathrm{~g}$ & 0,23 & 0,26 & 0,27 & $0,25 \mathrm{ab}$ \\
\hline $\mathrm{B} 4=200 \mathrm{~g}$ & 0,24 & 0,26 & 0,31 & $0,27 \mathrm{~b}$ \\
\hline Rerata & $0,22 \quad \mathrm{a}$ & 0,25 bc & $0,26 \mathrm{c}$ & \\
\hline BNJ bokasi kotoran ay & $(5 \%)=0,017$ & BNJ sal & ut kelapa $(5 \%)=0$ & 017 \\
\hline
\end{tabular}

Keterangan : angka rerata yang diikuti oleh huruf yang sama pada kolom dan baris yang sama berarti berbeda tidak nyata pada uji BNJ taraf uji $5 \%$

Hasil uji BNJ terhadap bobot kering total menunjukkan bahwa bobot kering total bibit tertinggi pada pelakuan B4 yaitu pemberian pupuk bokasi kotoran ayam $200 \mathrm{~g}$ dengan rata-rata $0,27 \mathrm{~g}$ berarti dapat meningkatkan bobot kering total bibit sebesar $27,72 \%$ dibanding perlakuan $\mathrm{B} 1$ dengan rata-rata $0,22 \mathrm{~g}$ (Tabel 4). Sabut kelapa $50 \mathrm{~g}$ per polibag memberikan bobot kering total bibit tertinggi pada perlakuan $\mathrm{S} 2$, yaitu 0,26 $\mathrm{g}$ yang berarti meningkatkan bobot kering total sebesar $18,18 \%$ dan yang terendah pada perlakuan tanpa sabut kelapa yaitu $0,22 \mathrm{~g}$.

Hasil uji lanjut BNJ pada taraf 5\% pemberian pupuk bokasi kotoran ayam menunjukkan perbedaan yang nyata terhadap tinggi bibit,bobot kering tajuk dan bobot kering total bibit. Pemberian pupuk kotoran ayam $200 \mathrm{~g}$ per polibag dapat meningkatkan tinggi bibit kelapa sawit hingga $16,93 \%$, meningkatkan jumlah pelepah $19,47 \%$, meningkatkan bobot kering tajuk $23,52 \%$ dan bobot kering total bibit 27,72\% dibandingkan dengan pemberian pupuk bokasi kotoran ayam dengan takaran $50 \mathrm{~g}$ per polibag. Tinggi tanaman, jumlah pelepah, diam- eter batang menggambarkan penambahan sel penyusun jaringan tanaman dalam proses pertumbuhan dan perkembangan bibit suatu tanaman, sementara bobot kering tanaman mencerminkan besarnya hasil fotosintesis yang membentuk jaringan atau organ tanaman.

Pemberian pupuk kotoran ayam dengan takaran $200 \mathrm{~g}$ per polibag diduga dapat memperbaiki sifat fisik, kimia dan biologis tanah didalam polibag, dengan meningkatkan kesuburan tanah dan kegemburan tanah. Meningkatnya kesuburan kimia dan membaiknya sifat fisik tanah menyebabkan akar tanaman dapat berkembang dengan mudah sehingga terjadi peningkatan penyerapan unsur hara terutama nitrogen, fosfor, dan kalium yang akan mempengaruhi pembentukan daun dan bagian tanaman yang lain (Lakitan, 2000). Widiana (1996) menyatakan bokasi menyuburkan tanah karena mengandung mikroorganisme yang bermanfaat bagi tanah, sehingga tanah menjadi lebih gembur dan dapat mempermudah pertumbuhan dan perkembangan akar. Membaiknya sifat fisik, kimia dan biolgis tanah akibat 
aplikasi pupuk bokasi kotoran ayam sejalan dengan penelitian Tendean et al. (2018) yang melakukan penelitian pemupukan bokasi kotoran ayam pada bibit tanaman lamtoro, menyimpulkan bahwa penggunaan pupuk bokashi kotoran ayam sebanyak 800 gram per polibag memberikan hasil yang terbaik pada tinggi tanaman, jumlah daun majemuk, dan jumlah anak daun pada tanaman lamtoro. Selain itu bokasi kotaran ayam dapat meningkatkan $\mathrm{pH}$ tanah sehingga ketersediaan unsur hara menjadi semakin tinggi bagi tanaman. Penelitian Nisa (2002), pemberian bahan organik dalam bentuk biochar dapat menaikkan $\mathrm{pH}$ tanah dari 6,8 menjadi 7,4. Bokasi meningkatkan populasi mikroorganisme fermentasi dan sintesis sehingga dapat meningkatkan ketersedian hara di dalam tanah, meningkatnya kapasitas tukar kation dan $\mathrm{pH}$ tanah melalui hasilasam-asam organik seperti asam humat dan asam fulvat yang berperan dalam meningkatkan porositas tanah yang berakibat pula membaiknya sirkulasi udara tanah (Goyal et al., 2004). Hal ini sejalan dengan pendapat Glauser et al. (2002),yang mengatakan aplikasi kompos akan meningkatkan pertumbuhan tanaman dengan memasok sejumlah nutrisi sekaligus berfungsi juga dalam memperbaiki sifat fisik, kimia dan biologi tanah. diduga karena pupuk bokashi asal kotoran ayam mengandung unsur hara yang lengkap dan $\mathrm{C} / \mathrm{N}$ rasio yang ideal (Hartatik \& Widowati, 2006).

Penambahan bahan organik kedalam tanah akan meningkatkan ketersediaan $\mathrm{N}, \mathrm{P}, \mathrm{K}, \mathrm{S}, \mathrm{Ca}$ dan $\mathrm{Mg}$ dan meningkatkan $\mathrm{pH}$ tanah. Kotoran hewan mengandung unsur hara $\mathrm{N}, \mathrm{P}$ dan $\mathrm{K}$ dalam jumlah yang dominan. Lakitan (2000) menyatakan bahwa nitrogen merupakan penyusun dari banyak senyawa bagi tanaman seperti asam amino yang diperlukan untuk pembentukan protein dan enzim. Pertumbuhan dan hasil akan semakin meningkat apabila protein dan enzim yang dihasilkan semakin banyak, karena protein dan enzim adalah bahan baku untuk pembentukan sel-sel baru yang mempercepat pertumbuhan. Kalium yang diserap tanaman merupakan aktivator dari berbagai enzim yang esensial dalam reaksi fotosintesis dan respirasi serta enzim yang terlibat dalam proses sintesis protein dan pati. Menurut Sutopo (1998) kemampuan tumbuh benih akan ditentukan oleh viabilitasnya, dan viabilitas salah satunya ditentukan oleh bahan kimia benih sebagai sumber cadangan makanan. Untuk pertumbuhan awal dari perkecambahan hingga lepasnya kotiledon maka cadangan makanan sangat berperanan besar dalam menentukan kualitas pertumbuhan bibit.
Hasil uji lanjut BNJ pada taraf 5\% menunjukkan pemberian sabut kelapa berpengaruh terhadap tinggi bibit, bobot kering tajuk dan bobot kering total dan tidak berpengaruh terhadap jumlah pelepah dan diameter batang. Pemberian sabut kelapa $50 \mathrm{~g}$ per polibag dapat meningkatkan tinggi bibit kelapa sawit 5,63\%, meningkatkan bobot kering tajuk 17,64\% dan bobot kering total bibit 18,18\% dibandingkan dengantanpa sabut kelapa.Hal ini diduga pemberian sabut kelapa sangat mempengaruhi metabolisme tanaman dalam penyerapan unsur hara dan air sehingga mempengaruhi pertumbuhan bibit kelapa sawit. Ketersediaan air yang cukup akan mempercepat laju transpirasi sekaligus meningkatkan laju penyerapan hara oleh tanaman. Sabut kelapa mengandung unsur hara makro dan mikro yang dibutuhkan tanaman diantaranya adalah kalium, fosfor, kalsium, magnesium dan natrium. Selain itu, dapat menahan air dan unsur kimia pupuk serta menetralkan kemasaman tanah.Secara fisik, mempunyai struktur yang dapat menjaga keseimbangan aerasi dan bersifat remah sehingga air dan udara mudah masuk.Kelembaban tanah akan meningkatkan aktivitas mikroorganisme tanah. Cahyono (2003) menambahkan kelembaban udara dan tanah yang sesuai akan meningkatkan pertumbuhan bibit tanaman. Penambahan sabut kelapa ke dalam polibag yang akan mengalami dekomposisi dan melepaskan senyawa gula dan protein yang dapat membantu aktivitas mikroorganisma tanah yang selanjutnya akan mendekomposisi bahan organik di dalam polibag. Nyakpa et al., (1998) menyatakan bahwa dalam kondisi kadar air tanah di atas kapasitas lapang maka pertumbuhan akan lambat karena terhambatnya perkembangan akar yang akan disebabkan oleh kurangnya oksigen dalam tanah. Jika jumlah air yang tersedia dalam tanah sedikit akan menyebabkan tanaman menjadi layu.

\section{KESIMPULAN}

Pemberian bokasi kotoran ayam 200 g per polibag dapat meningkatkan tinggi bibit kelapa sawit hingga 16,93 $\%$, meningkatkan jumlah pelepah 19,47 \%, meningkatkan bobot kering tajuk 23,52 \% dan bobot kering total bibit $27,72 \%$ dibandingkan dengan pemberian pupuk bokasi kotoran ayam dengan takaran 50 g per polibag.Pemberian sabut kelapa 50 g per polibag dapat meningkatkan tinggi bibit kelapa sawit 5,63\%, meningkatkan bobot kering tajuk 17,64 \% dan bobot kering total bibit $18,18 \%$ dibandingkan dengan tanpa 
sabut kelapa. Tidak terlihat pengaruh interaksi kedua perlakuan secara statistik, namun terdapat kecenderungan kombinasi perlakuan bokasi kotoran ayam $200 \mathrm{~g}$ dan sabut kelapa $50 \mathrm{~g}$ per polibag memberikan hasil yang terbaik.

\section{DAFTAR PUSTAKA}

Anonimous. 2018. Kalibrasi Penyiraman Pembibitan Kelapa Sawit Shower Head System. Majalah Media Perkebunan Sumber Inspirasi Agribisnis, Edisi Juli 2018.Hal 58-59.

Ariyanti, M., G. Natali \& C. Suherman. 2017. Respon pertumbuhan bibit kelapa sawit (Elaeis guineensis Jack) terhadap pemberian pupuk organik asal pelepah kelapa sawit dan pupuk majemuk NPK. Jurnal Agrikultura. 28 (2): 64-67.

Asmono, D., Purba A.R., Suprianto E., Yenni Y., \& Akiyat. 2003.Budidaya Kelapa Sawit. Pusat Penelitian Kelapa Sawit, Medan.

Cahyani, S.S. 2003. Pengaruh Pemberian Bokashi Terhadap Sifat Fisik dan Mekanik Tanah serta Pertumbuhan Tanaman Pak Choi (Brassica chinensisL), sebuah skripsi.Dalam IPB Repository.

Cahyono, B. 2003. Teknik dan Strategi Sawi Hijau (Pattsai). Yogyakarta : Yayasan Pustaka Nusantara.

Corley, R,H,V \& P.B Tinker. 2016. The Oil Palm. Fifth Edition.Wiley Blackwell, UK. 639 pp

Direktorat Jendral Perkebunan. 2013. Lintasan 30 tahun tahun pengembangan kelapasawit.http:// ditjenbun.deptan.go.id/tanhun/berita-176-lintasan30 - ta hun-penge mb a n gan-kela pa sawit.html.diunduh pada tanggal 27 September 2017.

Efendi, R. 2014.Pengaruh Pemberian Asam Humat danfosfat Alam Terhadap Pertumbuhan Bibit Kelapa Sawit (ElaeisGuineensisJacq) Pada Main Nursery .(Skripsi) Fakultas Pertanian Universitas Taman Siswa Padang.

Effendy, I. 2016. Produksi beberapa genotipe jagung (Zea mays L) sebagai tanaman sela pada kebun kelapa sawit tanaman menghasilkan. Prospek Agroteknologi 5 (2):17-24.
Glauser, B.; Lehmann, J.; \& Zech, W. 2002. Ameliorating physical and chemical properties of highly weathered soils in the tropics with charcoal $-\mathrm{A}$ review. Biol \& Fertility of Soils, Vol. 35: 219-230.

Goyal, S.S., Dull, K., \& Kapoor, K.K. 2005. Chemical and biological changes during composting of defferent organic wastes and asesement of compost maturity. Biores Technology. 6:1584-1591.

Hartatik, W.\& L.R Widowati. 2006. Pupuk Kandang. hal 59 - 82. Dalam R.D.M. Simanugkalit, D. A. Suriadikarta, R. Saraswati, D. Setyorini, W. Hartatik (Eds). Pupuk Organik dan Pupuk Hayati. Balai Besar Litbang Sumber daya Lahan Pertanian, Badan Penelitian dan Pegembangan Pertanian, Bogor.

Hasriani, Dedi K. K. \& Andi S. 2013. Kajian Serbuk Sabut Kelapa (Cocopeat) Sebagai Media Tanam.Jurnal Departemen Teknik Sipil dan Lingkungan, Fak.Teknologi Pertanian, IPB

Herman, M \& D. Pranowo. 2011. Produktivitas Jagung Sebagai Tanaman Sela Pada Peremajaan Sawit Rakyat Di Bagan Sapta Permai Riau. Seminar Nasional Serealia.

Herviyanti, A. Fachri, S. Riza, Darmawan, Guanidar \& S. Amrizal. 2012. Pengaruh pemberian bahan humat dan pupuk P pada tanah Ultisol. Jurnal Solum $19: 15-24$.

Hidayat, T.C., I.Y. Harahap, Y. Pangaribuan, S. Rahutomo, W.A. Harsanto, \& W.R. Fauzi. 2013. Air dan Kelapa Sawit. Pusat Penelitian Kelapa Sawit. Medan. 47 hlm.

Jaleel, C.A., P. Manivannan, G.M.A. Lakshmanan, M. Gomathinayagam, \& R. Panneerselvam. 2008. Alterations in morphological parameters and photosynthetic pigment responses of catharanthus roseus under soil water deficits. Colloids surf. B: Biointerfaces. 61: 298-303.

Khairil, M,. A. A. Kamarozaman, I. Arifin, A. Ramadzan, \& N. Nasir. 2012. Evaluation of several planting media for oil palm (ElaiesGuineensis) seedlings inmain nursery, in Proceedings of the Soil Science Conference of Malaysia, Kota Bharu, Malaysia, April 2012.

Khan, M. M. Khan, M. Abbas, M. J. Jaskani, M. A. Ali, and H. Abbas. 2006. Evaluation of potting media for theproduction of rough lemon nursery stock, Pakistan Journal of Botany. 38 (3): 623-629. 
Lakitan, B. 2000. Dasar-Dasar Fisiologi Tumbuhan. Raja Grafindo. Jakarta.

Loekito, A. M. 1998. Bokashi: alternatif lain pupuk organik. Majalah Semai.

Nisa, K. 2010. Pengaruh pemupukan NPK dan biochar terhadap sifat kimia tanah, serapan hara, hasil tanaman padi sawah.Thesis.Universitas Syiah kuala. Banda Aceh.

Nyakpa, M., M. Lubis, S. G. Nugroho, S. Rusdi, D. M. Amin, G. B Hong \& H. .Baily. 1988. Kesuburan Tanah. Universitas Lampung. Lampung

Paiman, 2013. Perancangan Percobaan untuk Pertanian. UPY Press. Yoyakarta. 426 hal.

Risnah, S. P. Yudono \& A. Syukur. 2013. Pengaruh abu sabut kelapa terhadap ketersediaan $\mathrm{K}$ di tanah dan serapan K pada pertumbhan bibit kakao. Ilmu Pertanian. 16(2):79-91.

Rosa, R.N. \& S. Zaman. 2017. Pengelolaan pembibitan tanaman kelapa sawit (Elais guineensis Jacq.) di Kebun Bangun Bandar, Sumatera Utara. Bul. Agrohorti. 5 (3) :325-333.

Sari, V.I.,Sudrajat \& Sugiyanta. 2015. Peran pupuk organik dalam meningkatkan efektivitas pupuk NPK pada pembibitan kelapa sawit di pembibitan utama. J. Agronomi Indonesia. 43 (2) : 153-159.

Suryanti, D, \& Anom, E. 2014. Uji Beberapa Konsentrasi Pupuk Cair Azolla (Azolla pinnata) pada Pertumbuhan bibit kelapa sawit (Elaeis guineensis Jacq.) di Pembibitan Utama. Jurnal Online Mahasiswa (JOM) Bidang Pertanian, 1(2): 1-13.

Sutopo, L. 1998. Teknologi Benih. Rajawali Press. Jakarta

.Sutanto, R. 2002. Penerapan Pertanian Organik. Kanisius. Yogyakarta.

Susilawati, R. 2000. Penggunaan Media Kompos Fermentasi (Bokashi) dan Pemberian Effective Microorganism- 4 (EM-4) Pada Tanah Podzolik Merah Kuning Terhadap Pertumbuhan Semai Acacia mangiumWild, (skripsi)Institut Pertanian Bogor.
Tendean,M., D. A. Kaligis, D.Rustandi dan W.B. Kaumang. 2018. Pengaruh level pupuk bokasi kotoran ayam terhadap pertumbuhan Lamtoro (Leucaena leucocephala). Jurnal Zootek. 30 (1):44-49.

Tezara, W., V. Mitchell, S.P. Driscoll, \& D.W. Lawlor. 2002. Effects of waterdeficit and its interaction with $\mathrm{CO} 2$ supply on the biochemistry andphysiology of photosynthesis in sunflower. $J$. Exp. Bot. 375 (53): 1781-1791.

Waruwu, F., Simunihuruk, B.W., Prasetyo \& Hermansyah. 2018. Pertumbuhan bibit kelapa sawit di pre-nursery dengan komposisi media tanam dan konsentrasi pupuk cair Azolla pinnata berbeda.JIPI 20 (1):7-12.

Widiana, G.N, K. Riyalmu. \& T. Higa. 1996. Tanya Jawab Teknologi Efektif Mikroorganisme Departemen Kehutanan, Jakarta. 